\title{
I AM AN AFRIKANER WOMAN
}

\author{
Sindiwe Magona \\ University of the Western Cape
}

\section{DISLOCATING WOMEN}

In the run up to the first truly democratic elections in South Africa, the Afrikaner women issued a heartfelt cry: What have you done in our name? Did Black women understand the question? Twenty years later, many a black-black woman, "Bantu" in the terminology of yesteryear, have begun to feel the anguish of their Afrikaner Sisters. Indeed, I am become the Afrikaner woman of yesteryear - Guilty by Association.

The lesson? Power disempowers women and yet, in the final analysis, we are all held accountable for the ills of society. In essence, there is no 'other'

September 7, 2015

\section{AM AN AFRIKANER WOMAN}

I, am an Afrikaner woman.

Yes.

Oh, yes, I am.

Am

An Afrikaner Woman.

Look at me.

Stop, and take a good

Look at me.

A very, very good look

Of me.

Look!

Look!

I, am an Afrikaner Woman.

For years, decades even -

You, sealed my lips

With your lies

Your deceit

You sealed my lips. 
Woman! You said,

This, God ordained!

I obeyed.

Woman, you said,

This is Tradition!

I obeyed.

Woman, you said,

This is Truth

It shall save you and

Your children to the third,

The forth, the nth Generation

For, it is ordained

God ordained.

I obeyed.

Was there never a misgiving

Deep down my belly?

Did my heart never

Oft-times flutter and sigh -

With slight motherly misgivings?

Did never a shy and timid tear

From ever so careful eye

Sometimes escape?

Yes.

Yes! Yes! And Yes, Yes, Yes.

A million million times

Yes!

But Religion

Tradition

Die Volk

You

They all sealed my lips

Die Volk

Tradition

Religion

You You You

They all sealed my lips.

You, sealed my lips.

BUT

Oh, God above!

Above all these

Above God, religion, die volk, tradition

And above

You -

(C) Magona and CMDR. 2015 
Fear sealed my lips.

Fear sealed my lips.

Fear ...

Then, when nothing could stop truth

When, truth burst upon our heads

Thunderous as storm rain

Then, like the silver swan

My silent lips wide did open.

Yes, lips long fear-sealed

Unsealed, my long silent lips

S C R E A M E D: WHAT HAVE YOU DONE, IN OUR NAME?

I, AM AN AFRIKANER WOMAN

Today, black as I look

Inside ... inside, I bleed

Bleed as the Afrikaner women

Bleed as the Afrikaner women

Only yesterday - NO! This morning,

That soon it was when the

Afrikaner women

Asked: WHAT HAVE YOU DONE IN MY NAME?

I ask

I ask

Today ... today, I ask

WHAT IS THIS YOU ARE DOING IN MY NAME?

WHAT ARE YOU DOING IN MY NAME?

Today - I am an Afrikaner Woman. 